\title{
Urban Housing Politics: Dynamics, Challenges and Coping Mechanisms of Urban Housing Problems in Sebeta Town
}

\author{
Efa Tadesse Debele \\ Department of Sociology, Addis Ababa University, Addis Ababa, Ethiopia
}

Email address:

efatdss@gmail.com

\section{To cite this article:}

Efa Tadesse Debele. Urban Housing Politics: Dynamics, Challenges and Coping Mechanisms of Urban Housing Problems in Sebeta Town. Journal of Human Resource Management. Vol. 7, No. 4, 2019, pp. 93-98. doi: 10.11648/j.jhrm.20190704.13

Received: August 10, 2019; Accepted: October 28, 2019; Published: October 31, 2019

\begin{abstract}
Urban housing demand is increasing with alarming rate in urban centers due to various factors instigate the demand. However, urban housing problems are not adequately emphasized by local urban administration and social thinkers in accordance with the seriousness and urgency of urban housing problems. This scenario produces multiple predicaments which complicates urban residents living condition mainly in terms of housing. In fact, urban residents tend to use different means to access their housing needs. The most predominantly prevalent housing option is housing rental which is not well investigated and incorporated into urban policy. Housing rental for residential purpose is highly neglected issue. Nevertheless, urban housing rental issue is demanding issue that requires proper attention. Furthermore, the most important point is the nature, patterns and degree of relationship between rentors and renters which need to be considered in critical manner. There are dynamics, challenges and controversies in relation to housing rental particularly for residential purpose. Sometimes residents who are offended by housing rental and shortage of urban housing supply enforced to engage in squatter settlement in order to meet housing demand in illegal or informal way. But, all squatter settlements are not initiated by urban poors rather urban capitalists or speculators can inevitably involve in squatter settlements which complicate the urban housing supply, demand and management. This study dedicated to investigate urban housing problems such as shortage, supply and management, dynamics of urban housing demands, challenges of urban housing rental, coping mechanisms of urban housing problems and associated squatter settlements.
\end{abstract}

Keywords: Housing Demands, Housing Rental, Rentors and Renters, Squatters and Speculators

\section{Introduction}

Currently, the ever grown urban trend results in tremendous urban problems. Those urban problems are triggered by different contributing factors. Even though there are multiple factors population growth, rural-urban migration, absence of good governance and several both internal and external factors are basically common. The most serious and demanding urban problem is urban housing which become more severe in largest city. Similarly, because of aforementioned reasons and other factors nowadays urban housing issue is becoming urgent issue particularly in developing country like Ethiopia.

Despite the magnitude of urban housing problem the attention given to this issue is very neglectful. The local municipality did not pay much attention to this issue. Urban policy and urban plan launched in city or town did not prioritized urban housing problem. This trend complicated urban overall problems because housing issue is the mother of all other issues. The policy and plan that well address the urban housing problem more likely can address other related issues. So urban housing problem need to be prioritized just because of its necessity and its vitality for addressing other urban issues. There is urgent need to regulate the residential growth of the city in planned manner [1]. Furthermore, scholarly discussion in this area is scanty. Therefore, urban housing problem need special attention and adequate investigation. This is a main triggering or motive of this specific study.

\section{Research Objectives}

The objectives of this research:

1. to identify contributing factors for urban housing 
problems,

2. to investigate problems associated with housing rental for residential purpose,

3. to identify challenges associate with urban housing problems and its management as well as housing development and

4. to examine the association between urban housing problems and squatter settlement.

\section{Method}

The principal research method used in this qualitative approach is in depth Interview techniques. In interview process, first and foremost, researcher introduced his name and express his objective to conduct interview. After researcher proved the willingness of his interviewees to respond his research questions then researcher continued asking topic questions or topic guide which is summary of lists of questions. The first question researcher asked was very general and open ended that researcher intended to stimulated the mind of the interviewees. The first question says" Can you tell me what the condition of urban housing problems in your town look like?". This question expected to encourage the respondent to react on this question and prepare $\mathrm{him} / \mathrm{her}$ to respond next related questions. So researcher believes this question is adequate question to start with.

In fact, researcher formulated the list of questions based on criteria of its openness and neutrality. Researcher sees that the flow of the interview is patterned in natural flow where researcher avoid jumping from one topic to another then back and forward rather researcher chose proceeding in order of topic lists. This was possible by deriving list of questions in accordance to main research objectives or research questions consecutively or in sequential manner. The questions were expected to be open to provide flexible and detail account of interviewee's experience on topic understudy. It was carefully drafted to make the questions as much as possible neutral enough.

In order to achieve the aim of the interview by creating good atmosphere for interviewees so as to extract story from him or her to allow him/her providing researcher detail understanding of his/her personal experience which possibly helped researcher to gain relevant and adequate data. Therefore, researcher used both prompts and probing so as to saturate my data. In view of that, researcher prompted the interviewees by using some techniques such as uh, huh, mm and head nodding. Similarly, researcher probed the interviewee so as to encourage him to provide more elaboration on issue in question by using techniques such as anything else? Then what happened?

Researcher also summarized the answers provide by interviewee using both his word and respondents' word so as to approve respondents the acceptance of his/her information and its importance. Furthermore, researcher and interviewees were talking about some sensitive issues such as political issues. The interviewees penetrated into discussion then researcher encouraged interviewee by prompting and probing so as to continue and elaborate the issue. Researcher's respondents were very emotional and so aggressive with deep regret and grief. The most important thing that helps and facilitates their discussion was non-verbal communication. This influences the atmosphere of the interview in positive manner.

Of course, the position of the researcher or interviewer was almost partially value free. This does mean that the interviewer share humanistic emotion such as pains or suffering, injustices, tragedies, catastrophic conditions while pursuing fact finding activities. Furthermore, the interviewer refrained himself from entertaining personal characteristics, needs, interests, ambition, etc so as to respects ethics of research and promote the quality of gathered data. Of course, researcher's personal aspiration to concern on the issue possibly had impact on interview by doing it exhaustively. Even when researcher introduce himself researcher confirm that his concern is the issue under discussion. In addition, researcher introduced himself with his past experience on related research and current status that may possibly impact the interview.

Moreover, researcher identified learning points during this Interview process. The interview activities have its own pros and cons. The current interview shows difficulties that researcher need to tolerate and manage. For example, getting consent person by itself is very challenging. The interviewee is not easily captivated into interview there are hesitations not to participate. Another is whom to ask and where to arrange the interview. More importantly, it is time consuming, tiresome and difficult to manage transcription, translation and thematic organization perfectly. A lot learnt from this interview such as tolerance, sociability or rapport, skill of communication and being honest so as to create trust. Researcher also learnt from this interview the importance of conducting qualitative research and its power to dig out the facts and associate detailed contents.

\section{Results of Interview}

This part deals with the results extracted from in-depth interview. As it was written earlier this interview had some major and minor research questions to meet. The interview questions were done in accordance to the objectives of the research questions. Therefore, in the next sections researcher will try to focus on the results obtained from the in-depth interview.

\subsection{Factors Contributing to Urban Housing Problems}

Firstly, the interview questions concentrated on identifying contributing factors for urban housing problems. In view of that, the interviewees stated that urban housing problems are very complicated and very serious in their town. The problem's trend shows aggravation from time to time because of different contributing factors. The interviewees said that urban houses are being constructed every day. However, the urban house constructions are not legal rather more or less 
many of them built through illegal way or informal. In fact, the government does not pay adequate attention to the problem. All state holders should collaborate towards enforceable standards for houses already built and future builds in order to guarantee the city sustainable development [2].

There is no fair urban house distribution in Sebeta town because single rich man can have more houses but majorities of the residents are house renters. The interviewees articulated that the number of rural-urban migrants increased due to job opportunities associated with industrial expansion in town, lack of effective urban housing management system particularly residential houses, increment of residents living in town or population growth, lack of controlling mechanisms on housing rental costs, squatter settlement and related factors contributed for urban housing problems. The interviewees asserted that these factors are manageable if the adequate attention is paid and effective housing supply, management and development is designed and monitored. However, the interviewees added that due to lack of effective urban housing supply, management and development poor urban residents are enforced to suffer from uncontrolled housing rental charges which in turn provokes squatter settlement as coping mechanisms. This in turn creates unfair resource distribution between urban rich and poor because majority of urban squatter settlers are economic elites since poors fear not risk the amount he/she has for non guaranteed construction.

\subsection{Housing Rental and Associated Problems}

The interviewees said local administration has no substantive data of the housing rental for residential purpose in Sebeta town. According to the interviewees' response the residential housing rental has been neglected by administrative bodies. In this light, Ansah et al (2013) [3] asserts the city authorities could liaise with traditional leaders for land to be provided to private sector developers for the construction of apartments or hostels that are specifically geared to the needs of recent migrants. The interviewees say there is no recorded data on housing rental for residential purpose because of unknown reasons. The interviewees add the regulation of housing rental is no yet emphasized. Fair housing and legal protection is good for housing renters while it is dangerous and threathening for lazy landlords (all property management) [4]. Furthermore, the interviewees mentioned that the rentors have power to increase the cost of housing rental at any time deliberately so as to boost their personal profit regardless of the interest, income level and whether the renter afford or not. In this regard E. L. Glaeser et al. (2014) [5] reported concerning housing dynamics that the big puzzle in economics is the persistent housing price changes whereas S. Belskyet al. (2005) [6] states that housing rental affordability issue is very difficulty issue to set yardstick to say unaffordable or affordable which is too political. The below is quoted from the interviewee's talk. '... the housing rent increases or additionally charged from time to time is what I experienced seven years consecutively adding fees year to year. I first rented by 600 ETB then after seven years the amount I asked to pay becomes 1, 500ETB, but my income has no significant difference. Finally, I forced to leave that house due to income differential of my earnings and housing rental fee".

So many renters enforced to pursue subsistence livelihood because what they earn and pay for housing rental cost has big difference. The interviewees said that the housing rental is not fair rather interviewees confirmed that housing rental is similar with labor exploitation. Rents are rising faster than incomes for a growing segment of families in almost every part of the country. This trend is primarily the result of (1) widening income inequality, with incomes rising slower for low- and moderate-wage workers than for those in high-skill, high-wage jobs, combined with (2) the fact that new housing construction is not keeping pace with employment and population growth in many metropolitan areas, and constrained supply in the face of increasing demand inevitably implies increases in home prices and rents [7]. Moreover, the interviewees says that the rentors are all what the rentersare not which mean the rentors interfered into private life of renters by restricting his freedom, dissociating renter from his reference groups or relatives and friends and the worst is some rentors do not rent their house to couples and family with children assuming that renters' consumption will be increased that decrease their profit from rental income. In areas where housing rental is in high demand land lords prefer not to rent their properties to low-income tenants [8]. Renters have been less security in living situation than those who own homes [9]. For this conflicting interest between renter and rentor always there is no harmony relationship between them. They encountered conflicts on cases such increasing housing rental, restricting social networks of renter, strict control over private life of renter, disobeying and disrespecting rentors, etc trigger the hostile relationship between renters and rentors. Yet, there is no administrative body that can interfere into such case that makes the conflict intractable.

\subsection{Urban Housing Challenges}

As discussed earlier urban housing problems become demanding issue. The interviewees stated that even though urban housing problems are alarming but no necessary attention is given. The attempts to reduce urban housing problems hitherto are none existent. The interviewees identified challenges that aggravates urban housing problems that residents are expected to suffer from. In view of that challenges are: land grabbing by political elites and economic elites, squatter settlement that accompanied by discriminatory confiscation of house constructed in which the speculator legalized but squats are outlawed forever and the existing real estate investment does not consider the capacity of poor while supplying urban housing they only sell to wealthy and political elites who can afford. In this regard Mari et al. (2014) [10] reported that government have not done enough towards meeting the housing needs of the people in the state particularly the low income class, most of 
the public housing scheme established by government those not favor the interest of the low income class considering the cost of the government rented quarters and the conditions for benefiting from some of these housing schemes. In addition, the local administrative or kebelehas urban houses that have been regulated under government but nowadays these houses are in tragedy because some of these houses are missed and no one knows where these houses are. In this case UNHABITAT (2011) [11] states that urban housing policies are often biased in favor of homeowners and fail to take into account the needs of tenants or renters. Of course, these houses are not taken somewhere but they are transferred from government ownership to private ownership illegally via collaboration of political and economic elites. The economic elites have enormous power to alienate houses and if any protest they intimidate them and they work cooperatively with local cabinets. Furthermore, these aggravate squatter settlement and illegal constructions in which many apartments now become ownerless. In this regard Watcher (2018) [12] mentioned that insufficient public and private investments in housing in the face of rapid urbanization over the years has resulted in the development of crowded informal settlements, sometimes in vulnerable areas, often without title or ownership rights. Housing finance has become an increasingly important issue, especially as squatting as a route to access land has become scarcer around urban areas [13]. Formal house construction does not keep pace with population growth in urban centers. The land trade and brokers role is very critical issue that needs attention.

\subsection{Squatter Settlement}

The final issue researcher and interviewees discussed in their interview was the association between urban housing problems and squatter settlement. The respondents uncovered the trends and complexity of urban housing problems and squatter settlement in which he/she stresses that squatter settlement issue is very complicated issue in which many actors advance their own interest at expense of the majority interest. The richer goes further from center to periphery so as to buy cheap land (squatter settlement) and to have more space rather than access but poor persisting living in downtown so as to access which is paradoxical [14]. The interviewees said that squatter settlement aggravated because of the engagement of economic elites for special interest or profit. He states that economic elites involve in squatter settlement deliberately. They are not squats but speculators that intend to achieve economic gain in the long run. Lack of housing options for growing population has driven ever increasing numbers into informal shelters [15]. Government does not take serious action on elites because those economic elites and political elites have relationship. On the other hand, poor people or residents who have no house also engage in squatter settlements. Haphazard arrangements of informal housing settlements on the outskirts of cities as well as near the urban centers give an image of poor urban management [16]. This type of settlement is necessity because the actors involve in it just to access house or shelter not for other economic purpose. For poor people squatter settlement is a means to meet basic need that is shelter. Furthermore, Bartesaghi (2011) [17] states that even though squatter settlements legitimacy is unconventional its positive implication require self housing, infrastructure growing and self sustainability commitment from community understudy whereas Pojani (2013) [18] asserts that squatter settlements provoke otherness between settlers and formerly rural traditional community that is challenge to bring full economic and social integration. However, the local administration takes serious action on their house and destruction of illegally constructed house is inescapable. In this regards, Bello (2009) [19] says" Ejection of squatters and demolition of illegal structures generates social, economic and political problems with their attendant security implications. It tends to portray government as insensitive to the plight of the citizenry. Demolition also results in financial losses both to the squatters and the government; and depletes the national housing stock. This approach is socially destructive and involves high community cost". This indicates the tragedy of the poor in the area and unfair treatment of citizens within a single town. The worst is the influence of rich people up to challenging the rules.

One interviewee says"... I know the person or the rich man who has twenty houses by different names. Some rich individuals also has the power to order landholding issue and I have information that one individual also remove from ICT his previous holding and get new landholding certificate without checking where is the previous holding,... this is very shocking",

Thus, the problem of squatter settlement is very sophisticated and complicated. Yet the main factor for squatter settlement is assumed to be unavailability of urban housing, absence of urban housing supply, management and development. In line with this $\mathrm{A}$, Elfarnouk (2015) [20] found that the reason behind the incidence and spread of squatter settlements is due to the failure of the state to implement of planning schemes and failure to adequate housing projects to accommodate the growing housing needs. The high building standards of the legal houses, delayed response and procedural problems of the legal land provision system, and high housing rent in the city centresare the major factors identified by respondents as reasons given for squatting. In addition, less government control over open spaces, limited capacity of the code enforcement service to control illegal housing construction, lack of comprehensive and consistent legal response towards the problem of squatting, and land speculators' practice of selling land for profit are other factors that have contributed to the emergence and proliferation of squatter settlements [21]. There is association directly or indirectly between urban housing problems and squatter settlement.

\section{Conclusion}

From this research it was found that indepth interview is 
very powerful to penetrate into the core issue. Accordingly from this research the following concluding remarks are drown. Firstly, the number of rural-urban migrants increased due to job opportunities associated with industrial expansion in town, lack of effective urban housing management system particularly residential houses, increment of residents living in town or population growth, lack of controlling mechanism on housing rental costs, squatter settlement and related factors contributed for urban housing problems. Secondly, the residential housing rental has been neglected by administrative bodies. The urban housing rental is not fair rather interviewees confirmed that housing rental is similar with labor exploitation. For this conflicting interest between renter and rentor always there is no harmony relationship between them. Yet, there is no administrative body that can interfere into such case that makes the conflict intractable. Thirdly, Urban housing challenges are: land grabbing by political elites and economic elites, squatter settlement that accompanied by discriminatory confiscation of houses constructed in which the speculator legalized but squatters are outlawed forever and the existing real estate investment does not consider the capacity of poor while supplying urban houses they only sell to wealthy and political elites who can afford. Finally, trends and complexity of urban housing problems and squatter settlement in which interviewees stress that squatter settlement issue is very complicated issue in which many actors advance their own interest at expense of the majority interest. Yet the main factor for squatter settlement is assumed to be unavailability of urban housing, absence of urban housing supply, management and development. There is association directly or indirectly between urban housing problems and squatter settlement.

\section{Recommendation}

In interview process researcher asked some questions related to possible solutions for urban housing problems and related squatter settlement. Accordingly, the following points are suggested to tackling both problems concomitantly. The government should allow legal settlement and even should construct cheap houses for urban poor. The government should be proactive of squatter settlement and take preventive action instead of curative action. The local administration may transfer illegally constructed houses to poor people rather than destroy the houses. Even some houses are constructed with better quality so destroying such houses is wastage of resources. But, if the government confiscate such houses and then transfer to urban poor who has no house there by government can mitigate urban housing problems. Therefore, confiscation of informal houses and its legal relocation to urban poor has several advantages. Firstly, it minimizes housing problems, punish speculators and secondly, it saves resources from wastages during destroy of squatter settlement. Moreover, the discriminatory treatment between squatters and speculators should be avoided. Furthermore, it recommended that housing rental needs to be standardized, government should control income of rentors, follow up the services of housing rental, agency need to be established so as to regulate housing rental associated issues, formulate formal agreement between renters and rentors concerning duties, rights, terms, costs and other related issues.

\section{Acknowledgements}

Researcher would like to give his special thanks to Professor Getnet Tadele, for his insightful mentor. Had it not been for his valuable counsel this article would not have appeared with its present form.

Researcher would like to express his sincere appreciation to Sebeta town Administration for giving researcher all the necessary support to access raw data. Researcher is also grateful to his in-depth interview informants and Sebeta town Offices staffs for their cooperation.

\section{References}

[1] Adeoye, Dorcas Oluwaseyi. 2015. Urban Planning and Architecture Design for Sustainable Development, UPADSD 14- 16 October 2015: Challenges of Urban Housing Quality: Insights and Experiences of Akure, Nigeria. Procedia - Social and Behavioral Sciences 216 (2016) 260-268.

[2] A. Elfarnouk, Nouri. 2015. Squatter Settlements In Tripoli, Libya: Assessing, Monitoring, And Analyzing The Incidence And Prevalence Of Urban Squatter Areas In The Peri-Urban Fringe; Submitted to the graduate degree program in Geography and the Graduate Faculty of the University of Kansas in partial fulfillment of the requirements for the degree of Doctor of Philosophy.

[3] A. Kuchay, Nissar, Bhat, M. Sultan and Shafi, Nuzhat. 2016. population growth, urban expansion and housing scenario in Srinagar City, $\mathrm{J}$ and $\mathrm{K}$, India; Journal of Geography and Regional planning; Academic Journals; vol. 9 (1), pp. 1-11, january, 2016.

[4] All Property Management. 7Rental Property Sins; That 'll put you in the poor house; website; allpropertymanagement.com; tell: $888-238-8948$.

[5] Ansah, J. K. Owusu-and Addai, M. 2013. COPING WITH LIFE IN A SQUATTER SETTLEMENT: THECASE OF MIGRANT WOMEN IN KUMASI, GHANA Dept of Planning, KNUST, Kumasi; (C) 2013 Kwame Nkrumah University of Science and Technology (KNUST); Journal of Science and Technology, Vol. 33, No. 3 (2013), pp73-88; http://dx.doi.org/10.4314/just.v33i3.8.

[6] Bartesaghi, Carlos. 2011. Squatter settlements as social catalysts towards a sustainable urban development: A Positive Look At The Case of Villa El Salvador, Limu Peru; Australian Graduate School of Urbanism (AGSU); University of New South Wales, Sydney-Australia.

[7] Bello, Mustapha Oyewole. 2009. Squatter Settlement, Accessibility of Land and the Urban Poor; Mustapha Oyewole BELLO, Nigeria; Squatter Settlement, Accessibility of Land and the Urban Poor.

[8] FIG Working Week 2009; Surveyors Key Role in Accelerated Development; Eilat, Israel, 3-8 May 2009. 
[9] Edward L. Glaeser, Joseph Gyourkoand, Eduardo Morales, Charles G. Nathanson. 2014. Housing dynamics: An urban approach; Department of Economics, Journal of Urban Economics; Harvard University, United States NBER, United States The Wharton School, University of Pennsylvania, United States Department of Economics, Princeton University, United Statesarticleinfo Articlehistory: Received 4 January 2013 Revised 30 January 2014 Available online 22 February 2014.

[10] Hacker, Steffan. 1998. The challenge of an urban world. 1998. An opportunity for US foreign Assistance; Section 3: Challenges in addressing Urban Growth and Housing Needs; Habitat for humanity international.

[11] Kingsley, G. Thomas. 2017. Trends in housing problems and Federal housing assistance; Metropolitan housing and communities policy center; Copyright (C) October 2017. Urban Institute. Permission is granted for reproduction of this file, with attribution to the Urban Institute. $2100 \mathrm{M}$ Street NW Washington, DC 20037 www.urban.org.

[12] Mari, Samuel Maina, Kura, Sani Mustapha \&Idris, Aliyu: A Study of the Problems of Public Sector Housing Schemes and How It Affects the Low-Income Class in Boron State, Nigeria; National Productivity Centre, Borno State Office, Federal Secretariat Complex, Maiduguri, Borno State, Nigeria: Ramat Polytechnic, Maiduguri, Department Of Social Services, P. M. B. 1070, Borno State, Nigeria; IOSR Journal of Humanities and Social Science (IOSR-JHSS) Volume 19, Issue 4, Ver. IV (Apr. 2014), PP 29-65e-ISSN: 2279-0837, p-ISSN: 22790845.www.iosrjournals.org.

[13] Malik, Sana and Wahid, Julaihi. 2014. Rapid urbanization: Problems and Challenges for adequate Housing in Pakistan; Journal of sociology and social work; december2014; vol. 2, no. 2, pp. 87-110. ISSN: 2333-5807 print; published by American Research Institute for policy development; DOI: 10.15640/jssw.v2n2a6:URL: http://dx.doi.org./10.15640/jssw.v2n2a6.

[14] Melesse, Minwuyelet. 2005. City Expansion, Squatter Settlements and Policy Implicationsin Addis Ababa: The Case of Kolfe KeranioSub-City; Working papers on population and landuse change in central Ethiopia, nr. 2NTNU Norges teknisk-naturvitenskapelige universitet, Fakultet for samfunnsviten skapog teknologiledelse Institutt for geografi Department of Geographyand environmental studiesAddis Ababa University ISSN 1502-2390 http://www.svt.ntnu.no
Addis Ababa University Det skapende universitet Acta Geographica-Trondheim Serie A, Nr. 9 Series A, No. 9Avhandlinger ograpporter Theses and reports Trondheim 2005.

[15] Philadelphia City Planning Commission. 2014. Renting in Philadelphia; A survey of tenants and landlords; The Melior Group; This report was prepared by Octavia Howell and Ian Lazzara of the Philadelphia City Planning Commission Staff. Funding for this report was provided by the William Penn Foundation. Research for this report was conducted by the Melior Group.

[16] Pojani, Dorina. 2013. From Squatter Settlement to Suburb: The transformation of Bathore, Albania. Housing Studies doi: 10.1080/02673037.2013.760031:

http://www.tandfonline.com/10.1080/02673037.2013.760031. website: https://www.researchgate.net/publication/263418018.

[17] S. Belsky, Eric, Goodman, Jack, And Drew, Rachel. 2005. Measuring The Nation's Rental Housing Affordability Problems; JOINT CENTER FOR HOUSING STUDIES HARVARD UNIVERSITY; Massachusetts Avenue 5th Floor Cambridge, $\quad$ MA $02138 \quad 617.495 .7908 \quad 617.496 .9957$ Fwww.jchs.harvard.edu.

[18] Ward, peter. M. 1976. The Squatter Settlement as Slum or Housing Solution: Evidence from Mexico City; See discussions, stats, and author profiles for this publication at: https://www.researchgate.net/publication/46552288; Article in Land Economics August 1976; DOI: 10.2307/3145530 Source: RePEc; author; Peter Ward; University of Texas at Austin.

[19] Watcher, Susan. 2018. Housing Challenges and New Urban agenda; Penn: Current Research On Sustainable Urban Development; Penn institute for urban research; Kleinman center for energy policy; perry world house.

[20] Willis, K. D. 2009. Squatter Settlements; Royal Holloway, University of London, Egham, UK; 2009 Elsevier Ltd. All rights reserved.

[21] UN-HABITAT. 2011. Quick Guides for policy makers: Housing the poor in Africa cities; 7Rental housing: A much neglected housing option for the poor; published by united nations human settlement programme (UN+HABITAT) Training and capacity building branch (TCBB); website: https://www.researchgate.net/publication/236974439. 